\title{
Tarpfazinės sąveikos ir kondensacijos tyrimai
}

Marijus Šeporaitis,

Mindaugas Valinčius,

Stasys Gasiūnas,

Darius Laurinavičius,

Raimondas Pabarčius,

Algirdas Kaliatka,

Kazys Almenas

Lietuvos energetikos institutas, Branduoliniu irenginiu saugos laboratorija, Breslaujos g. 3, LT-44403 Kaunas El.paštas Marijus.Seporaitis@lei.lt
Straipsnyje apžvelgiami 2005-2015 m. vykdyti skaitiniai ir natūriniai tyrimai besikondensuojančio dvifazio tekejjimo srityje. Pristatoma sukurta šiluminès-hidraulinès schemos koncepcija, kurioje šilumnešis cirkuliuoja varomas kondensacijos, eksperimentinis stendas, naudoti tyrimų metodai ir pasiekti rezultatai. Kombinuojant eksperimentų duomenis su skaitinio tyrimo rezultatais ištirta kondensacijos intensyvumo įtaka tarpfazinei trinčiai. Nagrinèjant turbulencijos struktūrą stačiakampiame eksperimentiniame kanale, optinès termografijos ir matematinès vaizdų analizès metodais aptiktas turbulencijos susižadinimo dvifazeje besikondensuojančioje tèkmëje reiškinys.

Raktažodžiai: kondensatas, turbulencija, dviejų fazių srautas, tarpfazinè sąveika

\section{IVADAS}

Stratifikuotas horizontalus besikondensuojantis dvifazis tekejimas vyksta ivvairiuose energijos gamybos, konversijos ir transportavimo bei chemijos technologiniuose irrenginiuose. Todèl dvifazis tekejjimas ir kondensacija jau daug metu yra plačiai tyrinejjami. Tačiau dèl tarpfazinès sąveikos sukeliamų procesų sudètingumo šis tekèjimo režimas nèra ištirtas iki pakankamo fundamentinio supratimo, o potencialiai panaudotinos tarpfazinès sąveikos ypatybės laikomos nepageidaujamais ir vengtinais reiškiniais. Pritaikius pažangesnius matavimo metodus atsiveria naujos galimybès gilinti žinias apie tarpfazinę sąveiką ir reiškinius, kuriuos ji sukelia besikondensuojančiame dvifaziame tekejime. Modeliuojant besikondensuojantị dvifazị tekèjimą, naudojamų koreliacijų pataisos koeficientų kitimo ribų platumas, vandens atveju, kelia daug abejonių jų naudingumu. Molekulinè dinamika net ir gana tolimoje perspektyvoje negalès būti praktiškai pritaikoma, tačiau baigtinių skirtumų metodai, jau naudojami dvifaziam tekèjimui modeliuoti, turi tokią perspektyvą. Korektiškas tarpfazinès sąveikos su faziniais virsmais sprendimas yra didžiausias modernių Skaičiuojamosios fluidų dinamikos (CFD) programų paketų kūrejų siekiamumas.

Lietuvos energetikos institute (LEI) tarpfazinès sąveikos ir kondensacijos tyrimai vykdomi nuo 1999 metų. Šiame straipsnyje apžvelgiami per pastaruosius dešimt metų atlikti eksperimentiniai ir skaitiniai tyrimai. Gauti rezultatai aktualūs tiek fundamentiniu, tiek praktiniu CFD vystymo ir panaudojimo plètros aspektais. 2005-2015 m. buvo rengiamos keturios disertacijos: „Nesikondensuojančio ir besikondensuojančio tekèjimu parametrų skaitinis tyrimas" (Stasys Gasiūnas, 2003-2007); „Dvifazio tekejimo ypatybiu panaudojimo pasyvioms aušinimo sistemoms tyrimas“ (Mindaugas Valinčius, 2005-2009); „Kondensacijos ir tarpfazinio paviršiaus nestabilumo ryšio tyrimas" (Darius Laurinavičius, 2009-2013); „Vietinių reiškinių tarpfaziniame garo-vandens 
paviršiuje tyrimas vykstant kondensacijai“ (Mindaugas Drūlia, 2013-2017). Šiuo laikotarpiu buvo vykdomi keturi biudžetiniai darbai: „Kondensacijos pliūpsnio tyrimas esant dvifazès sistemos nestabilumui“ (2005); „Kondensacijos ittakos tarpfazinio paviršiaus stabilumui tyrimas" (2008); „Besikondensuojančio dvifazio tekejimo eksperimentinis ir skaitinis tyrimas“ (2011); „Besikondensuojančios dvifazès tèkmès greičių lauko tyrimas horizontaliame stačiakampiame kanale" (2014). Tyrimų rezultatai plačiai publikuoti: 7 straipsniai Thomson Reuters duomenu bazejje Web of Science Core Collection referuojamuose leidiniuose, 10 straipsnių mokslo leidiniuose, registruotuose tarptautinèse mokslinès informacijos duomenų bazèse, 1 straipsnis kituose moksliniuose periodiniuose leidiniuose, 18 pranešimų konferencijose, iš kurių 9 tarptautinès; monografija "Evaporation/condensation of water. Unresolved issues. I. Phase change at low pressures, laminar conditions“ (Kazys Almenas, 2014).

\section{KONDENSACIJOS PLIŪPSNIŲ ŠILUMINĖ HIDRAULINE் SISTEMA}

Faziniai virsmai, kondensacija ir garavimas (virimas) - tai procesai, kurie pasireiškia daugelyje pramonès sričių: naftos, chemijos pramoneje, jie neatsiejami šiluminèse ir branduolinèse jegainèse. Šie procesai yra sudètiniai, netiesiniai ir norint spręsti kylančias aktualias problemas reikia atlikti sudètingus ir išsamius tyrimus. Staigios kondensacijos sukeliami tekejimai ir specifiniai reiškiniai gana plačiai nagrinèjami [1-6]. Tačiau pagrindinis šios krypties tyrimų uždavinys buvo nustatyti kondensacijos pasireiškimo ir jos sukeliamų reiškinių (skysčio tekejjimo, hidraulinio smūgio) sąlygas. Paprastai hidraulinio smūgio poveikis hidraulinei sistemai yra nepageidautinas, todèl siekiant saugiai eksploatuoti pramonès objektus mokslininkai pirmiausia nagrinèjo staigios kondensacijos sukeliamo hidraulinio smūgio priežastis ir kaip jų išvengti. Tuo tarpu LEI mokslininkai pateikè kitoki šiluminès energijos transformavimo ị mechaninị darbą būdą ir naują požiūrị ̣ staigios kondensacijos reiškinio taikymą pramoniniame objekte. Ankstesniuose LEI tyrimuose buvo įrodyta, kad kondensacijos pliūpsnis gali būti sukeliamas dirbtinai. Planuojant tolesnius tyrimus keltas tikslas - sukurti šilumines hidraulinès sistemos, kurioje vanduo cirkuliuoja dèl kondensacijos pliūpsnių, koncepciją ir pagrịsti sistemos veikimą ne tik avariniam aušinimui, bet ir normaliam darbo režimui.

Spręsdama iškeltą uždavinį LEI mokslininkų grupè sukūrè sistemos schemą, kurioje kontroliuojamo kondensacijos pliūpsnio reiškinys panaudotas šiluminès energijos transformavimui it darbą. Šiluminès-hidraulinès sistemos koncepcinè schema (1 pav.) susideda iš kontūro, kurio boileryje vanduo verda, o kondensatoriuje garas kondensuojasi. Sistemos darbui užtikrinti vanduo iš kondensatoriaus pumpuojamas $\mathfrak{i}$ boilerị. Vietoje boilerio gali būti bet koks šilumą vandeniui perduodantis įrenginys, kurị avarijos atveju būtina patikimai aušinti. Tokia pasiūlyta koncepciné sistema galètų būti panaudota ne tik avariniam aušinimui, kai nutrūksta energijos tiekimas iš išorès bei sustoja cirkuliaciniai siurbliai, bet ir normaliam darbo režimui su pasyvia šilumnešio cirkuliacija. Tai ypač aktualu šiluminèje ar branduolineje jègaineje.

Ciklo pradžioje boileris beveik visiškai užpildytas vandeniu, o kondensatorius beveik tuščias. Tokios būsenos sistema veikia efektyviausiai dèl maksimaliai išnaudojamų šilumos perdavimo paviršiu boileryje ir kondensatoriuje. Boileryje

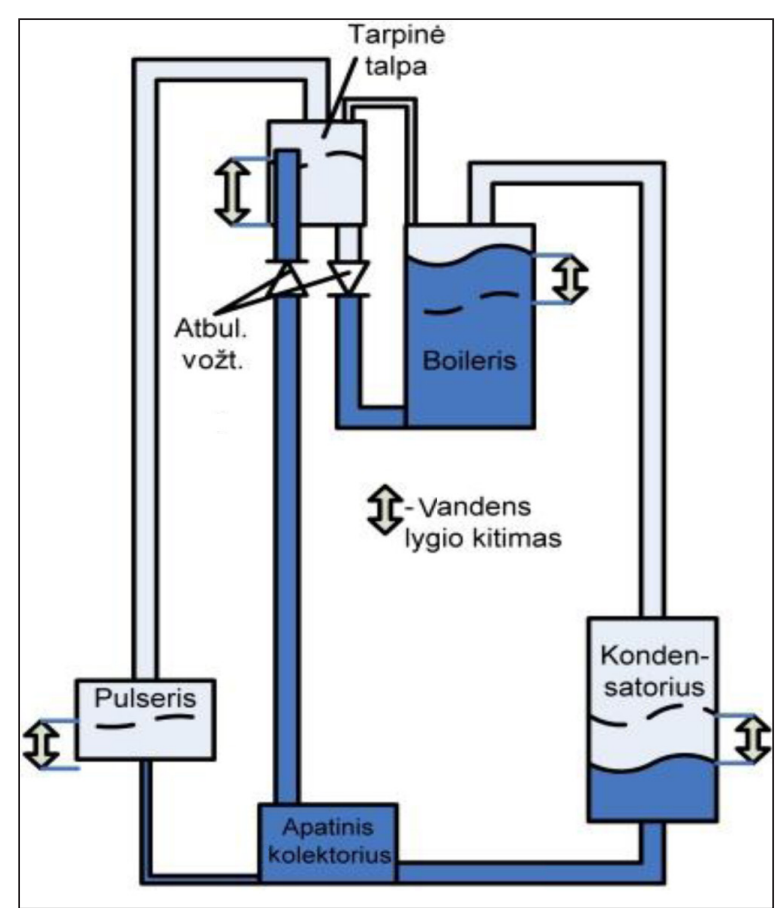

1 pav. Šiluminès-hidraulinės sistemos koncepcinė schema 
kaitinamas vanduo verda ir susidaro garas. Garas teka $\mathfrak{i}$ kondensatorių ir jame kondensuojasi. Kadangi nèra priverstinès cirkuliacijos, t. y. siurblių, boileryje vandens lygis mažèja, o kondensatoriuje - didèja. Lygiagrečiai boilerio-kondensatoriaus kontūrui prijungtas papildomas įrenginys - „pulseris", kuriame vandens lygis kinta kartu su vandens lygiu kondensatoriuje. I pulserị ịtekant šaltam vandeniui ir pakilus jo lygiui, analogiškai eksperimentų metu tyrinètam atvejui (ankstesni LEI darbai [7]), ịvyksta kondensacijos pliūpsnis. Jam ìvykus, pulseryje susidaro žemo slègio zona, link kurios dèl sleggio perkryčio teka garas ir vanduo. Tačiau vandens tiekimo ị pulserị vamzdis yra labai mažo diametro, todèl srautas ribotas. Pagrindinis kelias atstatyti slègių pusiausvyrą - vanduo turi teketti iš apatinio kolektoriaus ị tarpinę viršutinę talpą. Viršutinès talpos paskirtis - sumažinti slègi, kai boileryje vis dar yra vandens. Atvamzdžio iš boilerio ị tarpinę talpą reikia, kad tarp jụ susilyginus slègiams vanduo sutekètų $\mathfrak{i}$ boilerị. Šis atvamzdis taip pat yra labai mažo skersmens, todèl kondensacijos pliūpsnio metu garo srautas apribotas. Vandens tèkmès ị boilerị linijoje ịmontuotas atbulinis vožtuvas, neleidžiantis kondensacijos pliūpsnio metu vandeniui tekèti iš boilerio i tarpinę talpą. Taigi, proceso metu boileris vèl pripildytas vandens, kondensatorius beveik tuščias, o pulseryje esantis vanduo grižta ị kontūrą, ir ciklas kartojasi.

Kondensacijos pliūpsnio reiškini vienmačiu programų paketu, koks yra RELAP5, prognozuoti labai sudètinga [8]. Norint modeliuoti šiluminès-hidraulinès sistemos, kurioje vyksta kondensacijos pliūpsniai, veikimą, programų paketas buvo modifikuotas ir trikdis (kondensacijos pliūpsnis) sukeltas dirbtinai pagal eksperimentinio matavimo duomenis [9]. Nors i RELAP5 "idètas" kondensacijos pliūpsnio modelis ir nèra universalus, tačiau juo galima kondensacijos pliūpsnį atkartoti ir panaudoti modeliuojant visos šiluminès-hidraulinès sistemos veikimą, kai pats pradinis ịvykis žinomas iš anksto. Tai leidžia nustatyti sistemos parametrų kitimą bėgant laikui, iš kurių galima spręsti apie sistemos būsenas, pereinamuosius procesus, efektyvumą ir darbo ciklą.

Efektyviai veikiančiame pulseryje norimo slègio perkryčio kondensacijos pliūpsniai turi ịvykti esant tam tikroms sąlygoms, t. y. kai suteka pakankamas peraušinto vandens kiekis. LEI mokslininkų parinktas ir tyrimuose buvo taikomas modifikuotas Jacobs'o kriterijus $J a^{*}$ :

$$
\mathrm{Ja}^{*}=\frac{m_{f}(t) \cdot c_{p, f} \cdot\left(T^{s}(t)-T_{f}(t)\right)}{m_{g} \cdot h_{f g}}
$$

čia: $m_{f}(t)$ - peraušinto vandens, esančio tūryje, masè, $c_{p, f}$ - savitoji skysčio šiluma esant pastoviam slëgiui, $T s(t), T f(t)$ - soties ir vidutinès temperatūros, priklausomos nuo laiko, $m_{g}$ - pradinè garo masė, $h_{f g}$ - kondensacijos šiluma.

$\mathrm{Ja}^{*}$ yra šiluminès nepusiausviros kiekybinis parametras, nusakantis dvifazès tèkmès kondensacijos potencialą. Skaičiuojant ši parametrą buvo vertinamas illeidžiamo vandens kiekis bei garo kiekis pulseryje ir vamzdyje iki pulserio. Gautas geras rezultatų sutapimas (2 pav.) įrodo, kad eksperimentinių matavimų ir skaitinio tyrimo sąlygos buvo ekvivalenčios.

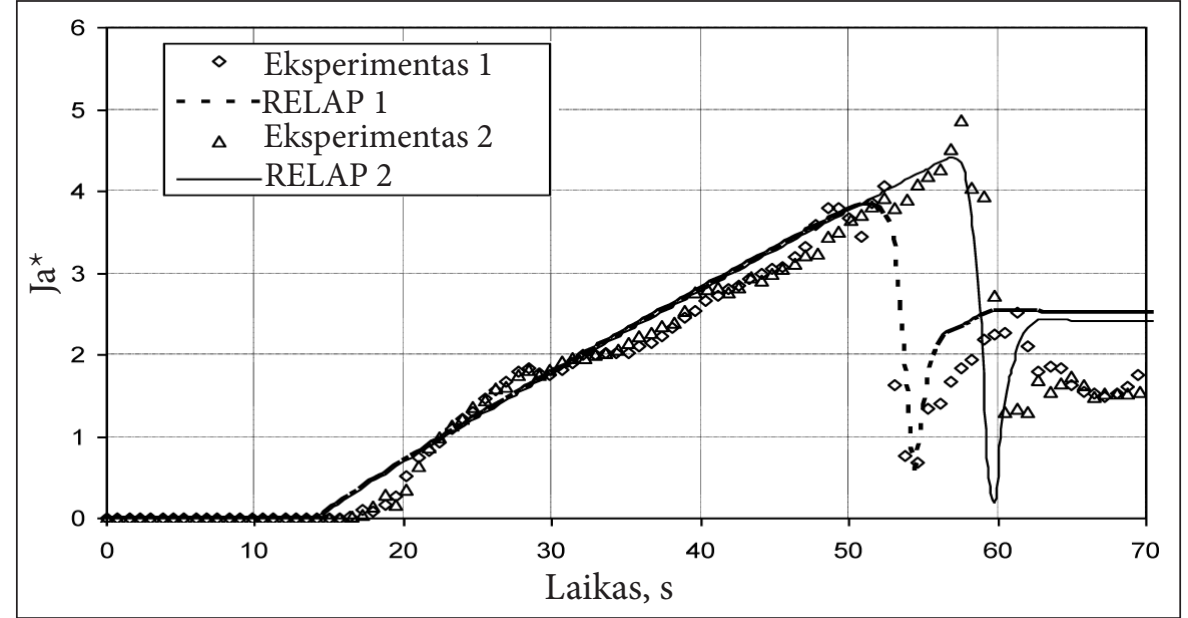

2 pav. Ja* kriterijaus kitimas pulseryje, vandens srautas $38,2(1)$ ir $37,8(2) \mathrm{g} / \mathrm{s}$ 


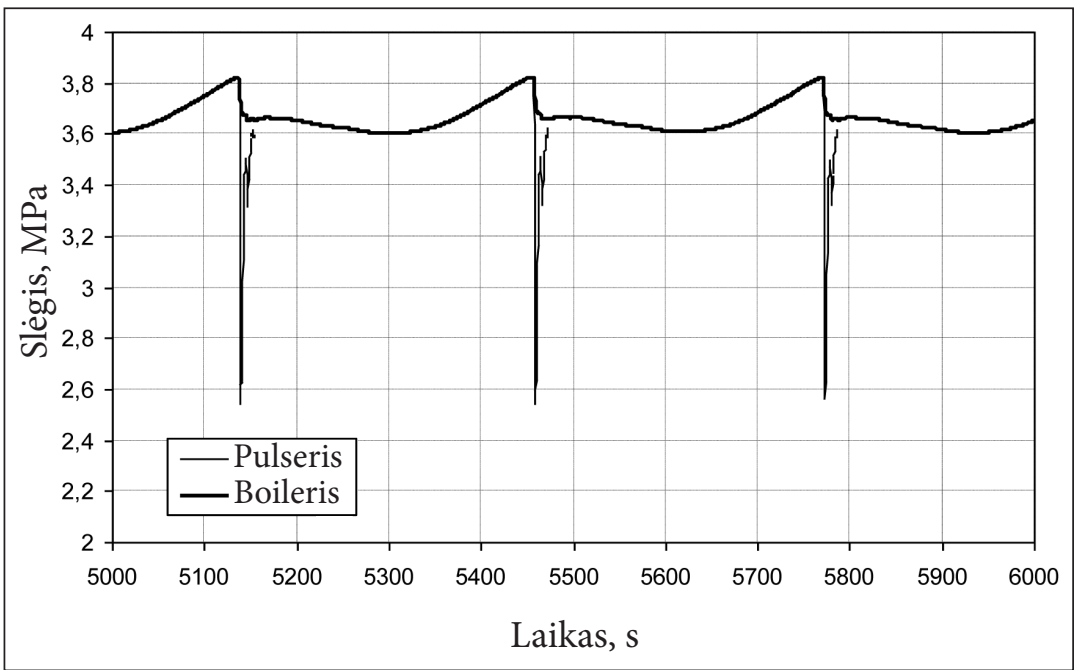

3 pav. Sistemos modeliavimo rezultatai. Slègis pulseryje ir boilerio viršuje

Siekiant patikrinti, ar gali vanduo cirkuliuoti kontūre dèl vykstančių periodinių kondensacijos pliūpsnių, ir teoriškai patikrinti koncepcinès šiluminès hidraulinès schemos veikimą, atlikti skaitiniai tyrimai jau minètu p. p. RELAP5. Kontūro geometrinès charakteristikos, kondensatorius ir boileris pasirinkti atitinkantys lengvojo vandens reaktoriaus realius įrenginius. Slèginiai indai kontūre išdèstyti pagal aukštị atsižvelgiant ị Ignalinos AE specifiką, boilerio šildymo galia priimta 27 MW. Tokia galia lieka praejjus maždaug 1 parai po reaktoriaus sustabdymo, t. y. tada, kai reaktorius gali būti aušinamas vien tik natūralios cirkuliacijos būdu nenaudojant cirkuliacinių siurblių. Kadangi natūrali cirkuliacija nebuvo modeliuojama, ị pulserị buvo ịleidžiamas tokios temperatūros vanduo, kokios jis išteka iš kondensatoriaus.

Skaitinio tyrimo rezultatai rodo (3 pav.), kad proceso metu pulserio linijoje slègis sumažeja, nors boileris yra beveik pilnas verdančio vandens. Jeigu pulseris būtų pajungtas be tarpinès talpos, jame slè- gio nepavyktų sumažinti tol, kol neišgaruotų visas boileryje esantis vanduo, ir tokia šilumine hidraulinė sistema su tuščiu boileriu veiktų neefektyviai, o galbūt ir pavojingai. Slègis pulseryje kondensacijos pliūpsnio metu sumažeja net 1,2 MPa (nuo 3,8 iki 2,6 $\mathrm{MPa}$ ), o pasiurbus vandens ị tarpinę talpą nusistovi apie 3,6 MPa slègis. Kylant vandens lygiui kondensatoriuje, jo efektyvumas mažèja, boileryje generuojama daugiau garo nei jo sukondensuojama, ir slegis po truputi pradeda kilti. Toliau ciklas kartojasi. Šj cikliškumą labai gerai iliustruoja ir minètas modifikuotas Ja* kriterijus (4 pav.). Boileryje nuvedamas šilumos kiekis taip pat nèra nekintantis parametras (5 pav.). Boilerio efektyvumas priklauso nuo jame esančio vandens lygio - kuo daugiau vandens, tuo efektyvesnis šilumos nuvedimas, žemesnè sienelès temperatūra, o dèl didesnio temperatūrų skirtumo išorinis šaltinis gali atiduoti daugiau šilumos. Tai ir matyti - didžiausia nuvedama 28 MW galia tada, kai vandens lygis boileryje didžiausias (vidutinè $27 \mathrm{MW}$ ).

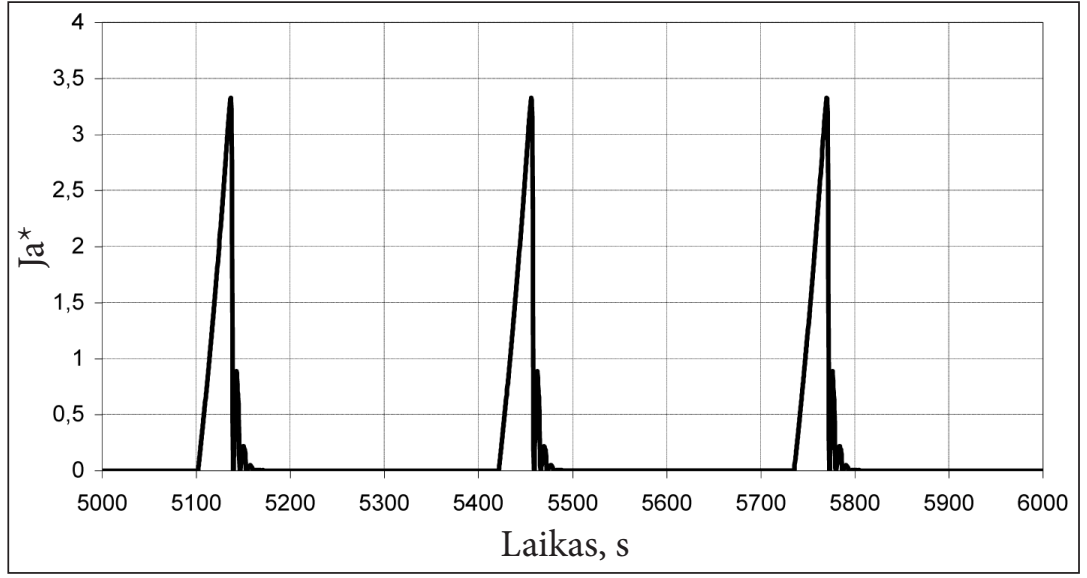

4 pav. Sistemos modeliavimo rezultatai. Kriterijus Ja* 


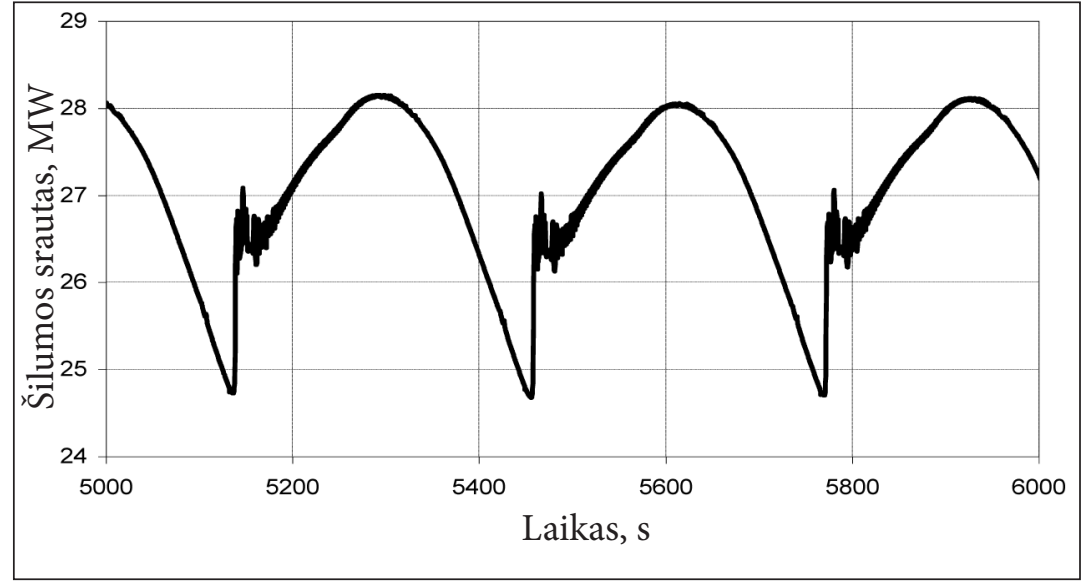

5 pav. Sistemos modeliavimo rezultatai. Šilumos srautas i boileri iš išores
Koncepcijos patikros tyrimo rezultatai patvirtino, kad nagrinèta šiluminè hidraulinè sistema veikia kaip ir tiketasi. Šis pavyzdys rodo, kaip ji gali būti pritaikyta branduolinèje jegaineje ir atlikti pasyvaus aušinimo funkcija. Tokio tipo sistemos gali būti naudojamos ir kituose pramonès įrenginiuose, kur generuojama šiluminè energija ir reikia užtikrinti šilumnešio cirkuliaciją kontūre. Tokios sistemos privalumas sietinas su saugia eksploatacija, ji yra pasyvi, nenaudojama papildoma išorine energija, nèra besisukančių dalių (kaip, pvz., siurbliuose). Vis dèlto siekiant pašalinti priimtas kai kurias griežtas kraštutines modeliavimo sąlygas (kondensacijos pliūpsnio prognozavimas, pradinis trikdis), reikejo atlikti išsamius eksperimentinius tyrimus, taikyti pažangius modeliavimo, programinių paketų sujungimo metodus ir pan. Būtent kondensacijos pliūpsnio susidarymo sąlygoms ištirti ir buvo atliekami tolesni fundamentiniai eksperimentiniai ir skaitiniai tyrimai. Tyrimai buvo vykdomi trimis pagrindinemis kryptimis:

- eksperimentinis garo sąveikos su vandeniu tyrimas stačiakampiame kanale;

- skaitinis garo srauto stačiakampiame kanale modeliavimas, siekiant nustatyti tarpfazinès šlyties ittempius;

- garo ir vandens paviršiaus sąveikos tyrimas, vizualizuojant sukeltą turbulenciją.

\section{KONDENSACIJOS İTAKOS TARPFAZINEI SĄVEIKAI TYRIMAS}

Daugelyje dvifazi stratifikuotą tekèjimą tyrusių eksperimentinių darbų buvo naudojami ilgi ir platūs kanalai. Ilgais kanalais siekta gauti nusistovëjusị tekejjimą, platesni kanalai buvo naudojami siekiant sumažinti šoninių sienelių ịtaką. Tačiau tiriant kondensacijos reiškinius nusistovejusio tekejjimo negali būti, todèl šiame tyrime LEI buvo naudojamas $1 \mathrm{~m}$ darbinio ilgio tarpfazinis paviršius, $\mathrm{o}$ siaurame kanale patogiau stebèti ir tirti reiškinius, vykstančius tarpfaziniam paviršiui statmena kryptimi. Nestacionarus tekèjimo ir kondensacijos režimas bei siekis panaudoti termoviziją vandens temperatūros laukui registruoti nulèmé naudojamo eksperimentinio kanalo vidinius matmenis $(1,2 \times 0,02 \times 0,1 \mathrm{~m})$. Prieš tarpusavio kontaktą vandens ir garo tèkmés stabilizuojamos panaudojant iš daugybės lygiagrečių kanalèlių (skersmuo 1 mm) sudarytą korinę prieškanalio struktūrą (6 pav. 9). Tokị stabilizavimo principą naudoja ir kiti tyrejai [10]. Kanalo pradžioje garą nuo vandens skiria $160 \mathrm{~mm}$ ilgio horizontalus peilis, o už jo prasideda tiesiogine tarpfazinè sąveika. Slègis kanale artimas atmosferiniam. Vandens ir garo ịtekëjimo ị kanalą ir ištekejjimo iš kanalo skerspjūviuose temperatūros matuojamos $\mathrm{K}$ tipo (Cr-Al) termoporomis (6 pav. $7,10)$. Vandens temperatūros laukas registruojamas termovizoriumi FLIR SC-5000. Eksperimentų metu garas ị kanalą tiekiamas 4,6 ir $8 \mathrm{~m} / \mathrm{s}$ greičiu, jo temperatūra $102-107^{\circ} \mathrm{C}$, kiekvieno atskiro eksperimento metu ji buvo palaikoma $1{ }^{\circ} \mathrm{C}$ tikslumu. Garo greitis matuotas kanalo viduryje ir gale, 0,55 ir $1 \mathrm{~m}$ atstumu nuo kanalo pradžios, panaudojant Pito-Prandtlio vamzdeli, sujungtą su elektroniniu skirtuminio slegio matuokliu „Fuji Electric FCXAII“. Skirtingų bandymų metu vandens vidutinis greitis kanale buvo 0,$0014 ; 0,0028$ arba $0,0056 \mathrm{~m} / \mathrm{s}$ (debitas 0,$025 ; 0,05$ arba $0,1 \mathrm{~m}^{3} / \mathrm{h}$ ), o jo pradine temperatūra 25 arba $50{ }^{\circ} \mathrm{C}$. Visų eksperimentų metu, esant skirtingiems vandens bei garo debitams ir siekiant išlaikyti vienodą $25 \mathrm{~mm}$ vandens lygi 


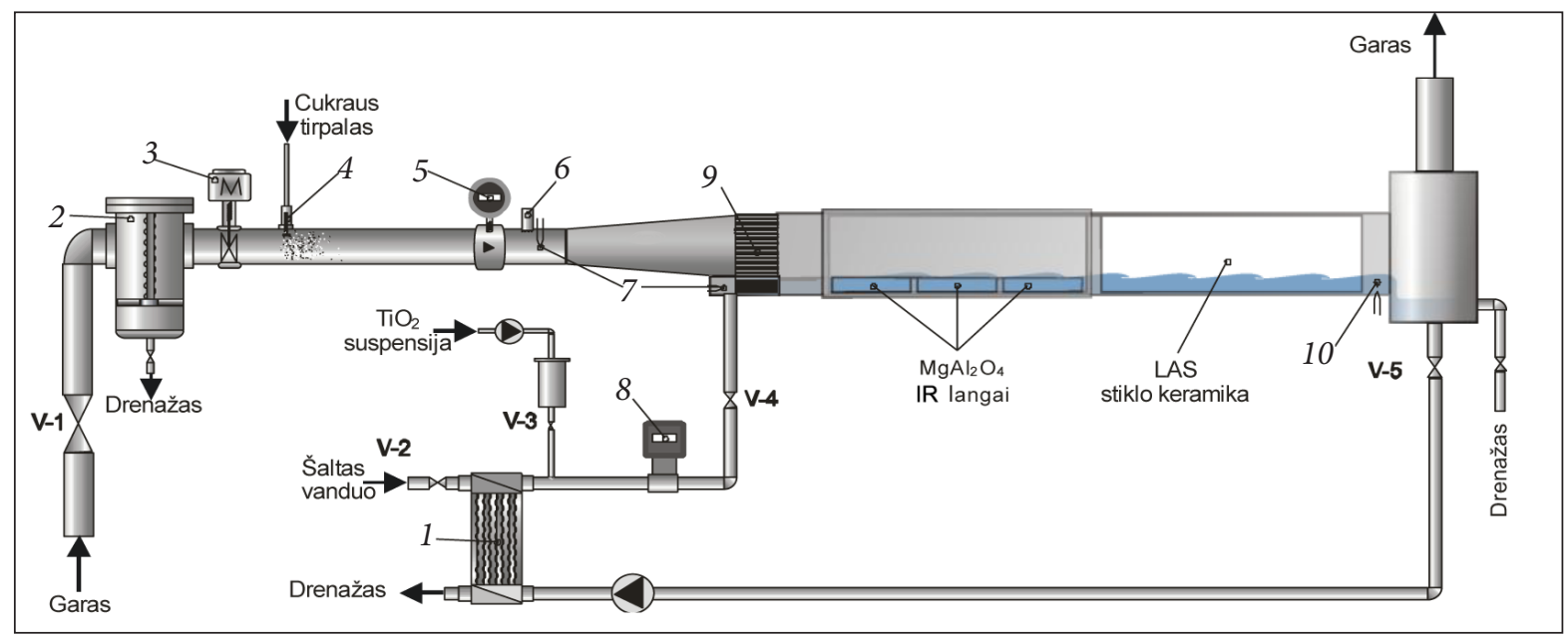

6 pav. Eksperimentinis stendas: 1 - šilumokaitis; 2 - separatorius; 3 - vožtuvas su pavara; 4 - ultragarsis purkštukas; 5 - garo srautmatis; 6 - slègmatis; 7 - termoporos; 8 - vandens srautmatis; 9 - prieškanalis; 10 - termoporų rinklè

visame kanalo ilgyje, buvo reguliuojamas kanalo posvyrio kampas.

Siekiant ịvertinti tarpfazinę sąveiką, reikia nustatyti, kiek garas trikdo vandens paviršiu bet kuriame tekejjimo skerspjūvyje. Tam reikia išmatuoti greičių profilius prie tarpfazinio paviršiaus. Techniškai racionalu tai atlikti tik keliose vietose ir gautus duomenis panaudoti kuriant realybei adekvatų modeli. Tekant garui kanale virš šaltesnio vandens, vyksta garo kondensacija ant vandens paviršiaus. $\check{S}_{\mathfrak{i}}$ procesą sumodeliuoti trimačiais programų paketais labai sudètinga dèl kartu skaičiuojamų dviejų skirtingų fazių fluidų tekejimo, vientisumo lygčių bei papildomai atsirandančiu šilumos, masès ir momento perdavimo per tarpfazinị paviršių.
Deklaruojantys galimybę spręsti tokius uždavinius programiniai paketai intensyviai tobulinami, tačiau gaunami rezultatai skiriasi, dar nèra parengta universali patikima skaitinio modeliavimo metodika [11]. Tarpfazinès šlyties ịtempiams nustatyti šiame tyrime buvo taikomas supaprastintas vienfazis trimatis skaitinis kanalo modelis (p. p. FLUENT). Supaprastinta modelio fizika kompensuojama sudètingesne geometrija, t. y. priimta, kad garas išteka ne tik per pagrindinị ištekejimą kanalo pabaigoje, bet ir per pusiau pralaidžią apatinę sienelę (išleidžiama 0-24 \% garo). Ji kondensacijos metu imituoja tarpfazini paviršiuc per kurị nuvedama dalis garo tèkmès (garo kondensacija ant vandens paviršiaus). Ši, per apačią nuvedama dalis, apskaičiuota

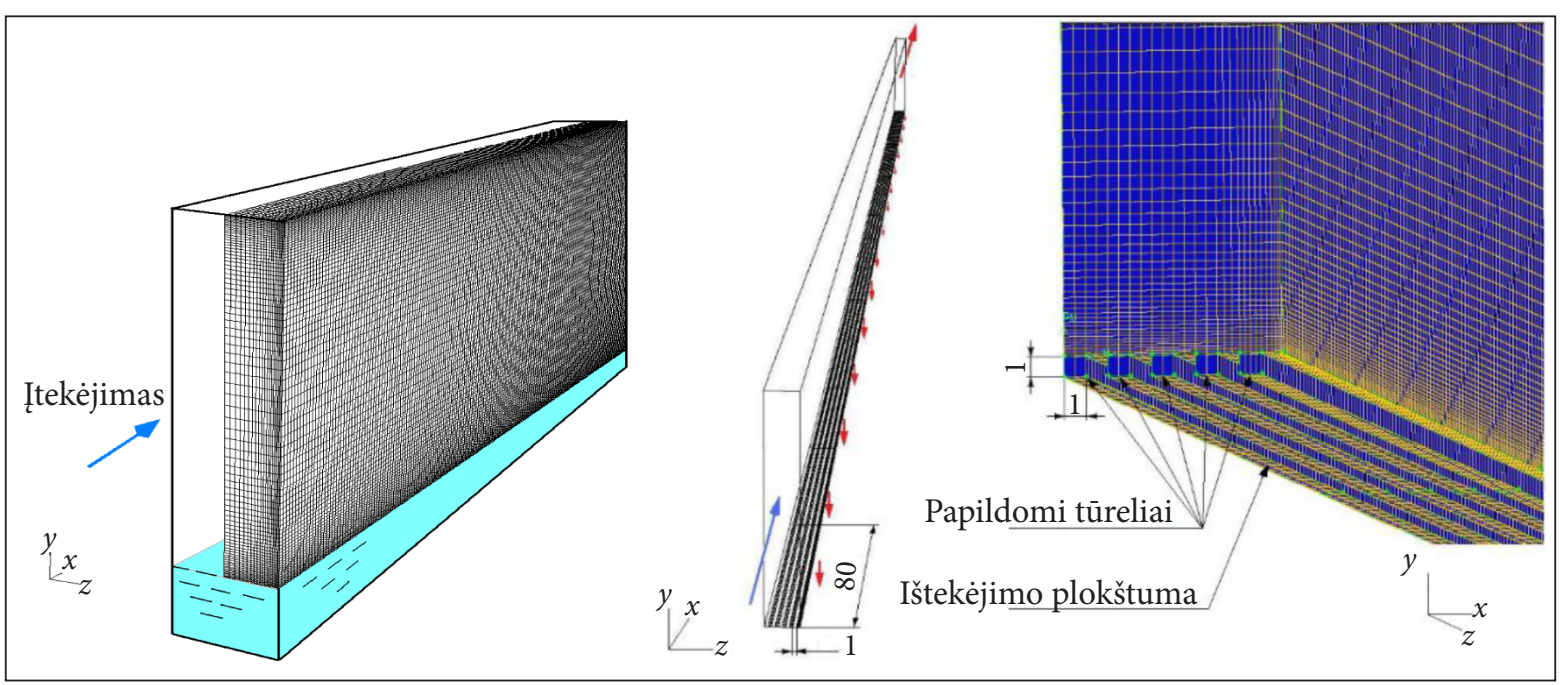

7 pav. Horizontalaus stačiakampio eksperimentinio kanalo skaitinis modelis (p/p FLUENT3D) 
pagal natūrinių eksperimentų rezultatus, todèl modeliuojama garo tèkmè turètų būti labai panaši ị realiai virš vandens tekančią ir besikondensuojančią i jo paviršių. Tokia skaitinio modelio geometrija leido įvertinti garo tèkmès kitimą kanale. Kadangi garo tèkmè kanale turbulentinè $(\mathrm{Re}=6000-$ 12 000), modeliuojant buvo taikytas standartinis $k-\omega$ turbulencijos modelis. Itekejjimo turbulencijos kinetinè energija $k$ ir sūkurių disipacijos laipsnis $\omega$ įtekejjime buvo apskaičiuoti pagal empirines išraiškas, pateiktas p/p FLUENT. Matavimų ir skaičiavimų pagrindinès pradinès sąlygos apibrèžtos vienodais garo ịtekèjimo greičio ir vandens tekèjimo srauto deriniais.

Kaip minèta, FLUENT3D modelyje garo ištekejjimas per apatinę pusiau pralaidžią sienelę priklauso nuo sleggio ir vyksta tolygiai per visą kanalo ilgi. Tačiau realybèje garas kondensuojasi ant vandens paviršiaus netolygiai pagal kanalo ilgi dèl kintančios vandens temperatūros, procesui taip pat įtakos turi šilumos pernešimo vandenyje ypatybès. Išmatuoti vidutinès vandens temperatūros profiliai (8 pav.) išilgai kanalo skirtingi, atsižvelgiant i garo ittekẻjimo ị kanalą greitị ir vandens tiekimo srautą.
Akivaizdu, kad esant $8 \mathrm{~m} / \mathrm{s}$ garo ịtekèjimo greičiui ir $50 \mathrm{l} / \mathrm{h}$ vandens tiekimo srautui ties $450 \mathrm{~mm}$ koordinate nuo įtekèjimo i̇vyksta kokybinis kondensacijos režimo pasikeitimas. Panašios vandens temperatūros profilio transformacijos matomos ir esant $8 \mathrm{~m} / \mathrm{s}$ ir $10 \mathrm{l} / \mathrm{h}$ bei $6 \mathrm{~m} / \mathrm{s}$ ir $50 \mathrm{l} / \mathrm{h}$ deriniams.

Pagal šiuos išilginius vandens temperatūros profilius apskaičiuoti kondensuojamo garo srautai. Vandens paviršių atstojanti pusiau pralaidi modelio apatinè sienelè suskirstyta ị 14 segmentų, kurių kiekvieno ilgis $80 \mathrm{~mm}$ (7 pav.), ir atskirai kiekvienam segmentui apskaičiuotas garo ištekèjimas, imituojantis kondensaciją (pvz., 9 pav.). Kondensuojamo išilgai kanalo garo srautas per iš dalies pralaidžią apatinę sienelę FLUENT modelyje, sąlygomis atitinkančiomis $10 \mathrm{l} / \mathrm{h}$ vandens debitą $(0,005 \mathrm{~m} / \mathrm{s})$, pradeda mažèti dar nepasiekęs kanalo vidurio (9 pav. 1-a laužtè). Vanduo tiesiog pašyla ir nebelieka temperatūros skirtumo kondensacijai vykti (žr. 8 pav.) Tačiau esant penkis kartus didesniam vandens srautui (9 pav. 2-a laužtè) kondensacijos intensyvumas dideja beveik iki pat kanalo pabaigos. Atrodo paradoksalu tai, kad nors garas perkaitintas, o vanduo peraušintas, nuo fazių kontakto

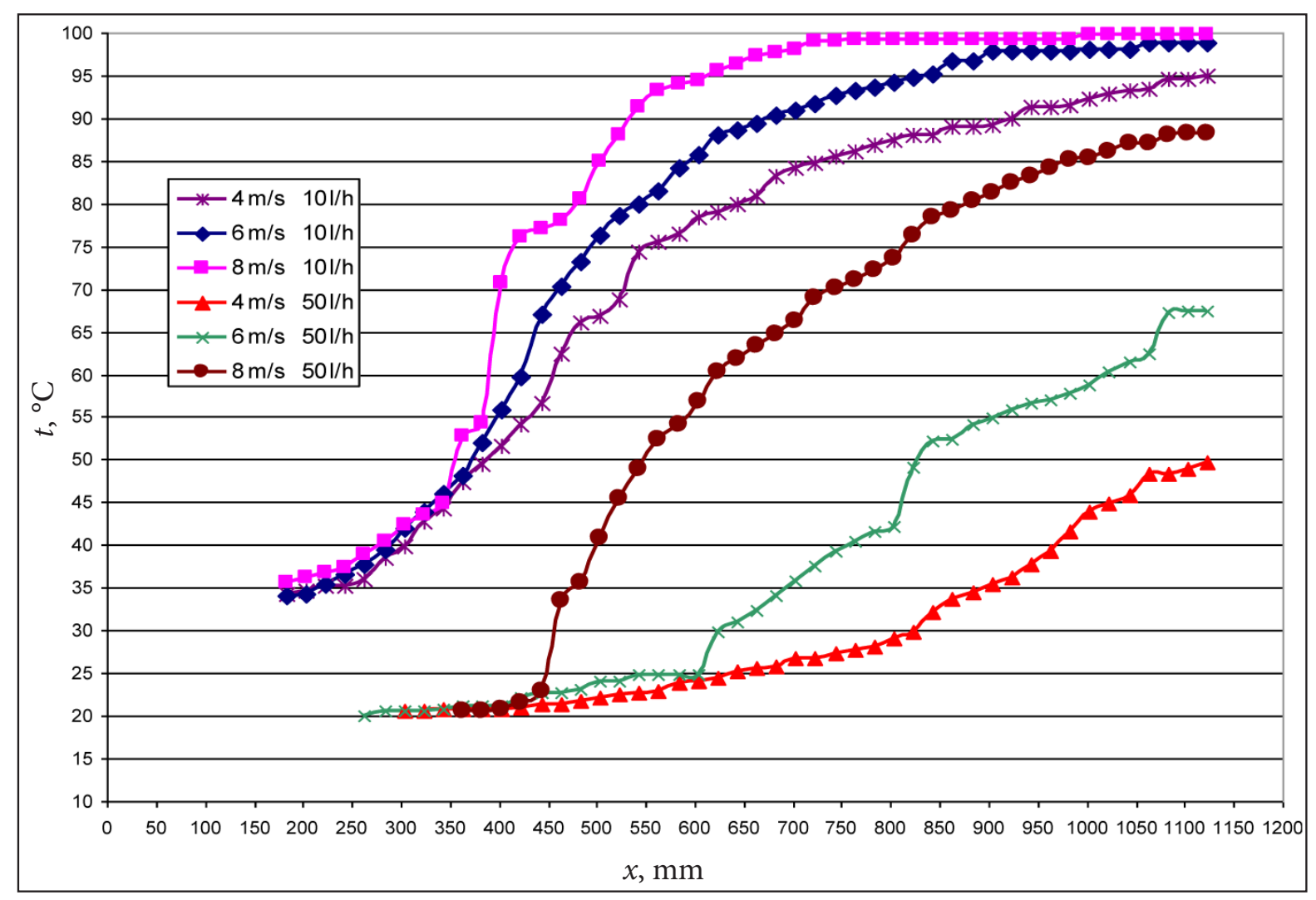

8 pav. Išmatuoti vidutinės vandens temperatūros profiliai pagal kanalo ilgi 


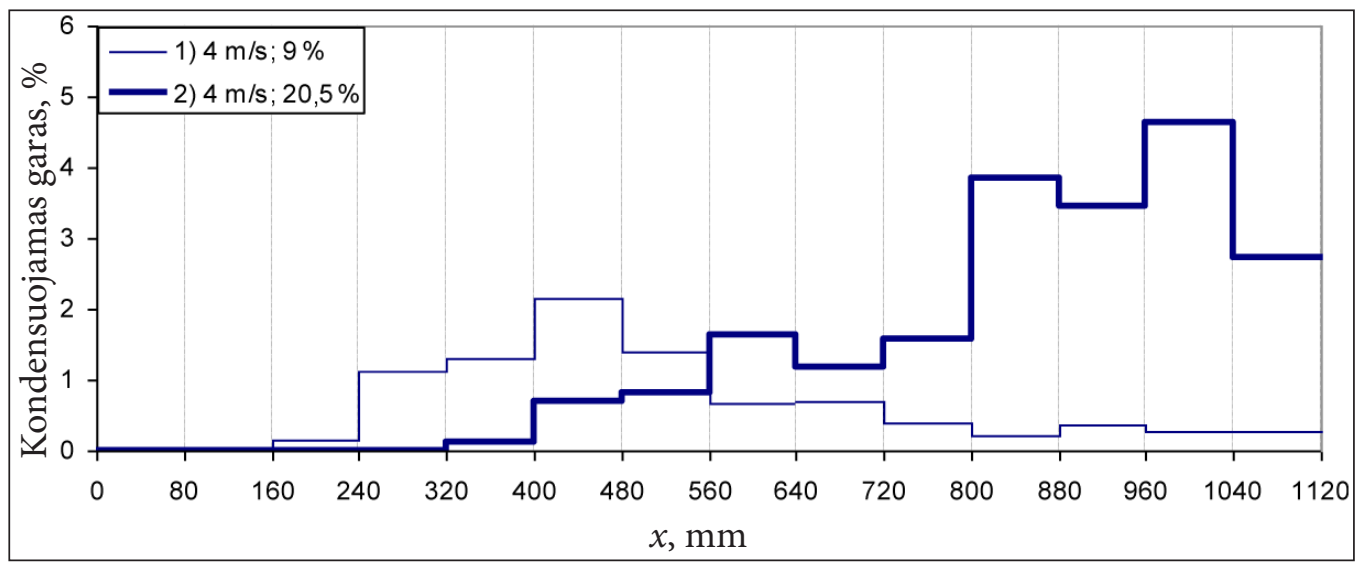

9 pav. Santykiniai FLUENT modelyje išvedami $4 \mathrm{~m} / \mathrm{s}$ garo j̨tekmès srautai, esant skirtingam suminiam santykiniam sukondensuojamo garo srautui $9 \%$ (1) ir 20,5\% (2)

pradžios šilumos srautas ne mažèja, o didèja ir pasiekia maksimumą tik tam tikru atstumu. Tai paaiškinama tuo, kad po vandens paviršiumi susiformuoja didelis tankio, taip pat ir temperatūros, gradientas. Didèjant garo greičiui (visais nagrinètais atvejais), kondensacijos intensyvumo pikas slenka kanalo pradžios link.

Kondensacija garo greičio profilio maksimumą perslenka arčiau kondensacijos paviršiaus ir suplonina hidrodinamini pasienio sluoksni. I skaitini modeli ịvedus eksperimentiškai nustatytą išilgini sukondensuojamo garo srauto profili (pvz., 9 pav.), o tada apskaičiuotus garo greičio profilius prie kondensacijos paviršiaus kontroliniuose taškuose sutapdinus su išmatuotaisiais (pvz., 10 pav.), gauti tarpfazinès šlyties ịtempių profiliai (11 pav.).
10 pav. pateiktame sutapdintų greičio profilių pavyzdyje matomi neatitikimai rodo modelio neadekvatumą realiam eksperimentui. Tačiau apačioje (prie tarpfazinio paviršiaus) rezultatų atitikimo lygis pakankamas ịvertinti tarpfazinę šlyti.

Iš natūrinių eksperimentų duomenų sumodeliuoti tarpfazinès šlyties įtempių profiliai leidžia ivertinti ir palyginti kondensacijos intensyvumo daromą įtaką. Nagrinejjant 11 pav. pateiktus modeliavimo rezultatus reikia turèti omenyje, kad kondensaciją imituojantis ištekejjimas per apatinę modelio sienelę pradedamas nuo $160 \mathrm{~mm} .11$ pav. aiškiai matyti, kad kondensacijos intensyvumo didèjimas gerokai stiprina tarpfazinę sąveiką. Esant $8 \mathrm{~m} / \mathrm{s}$ garo įtekèjimo

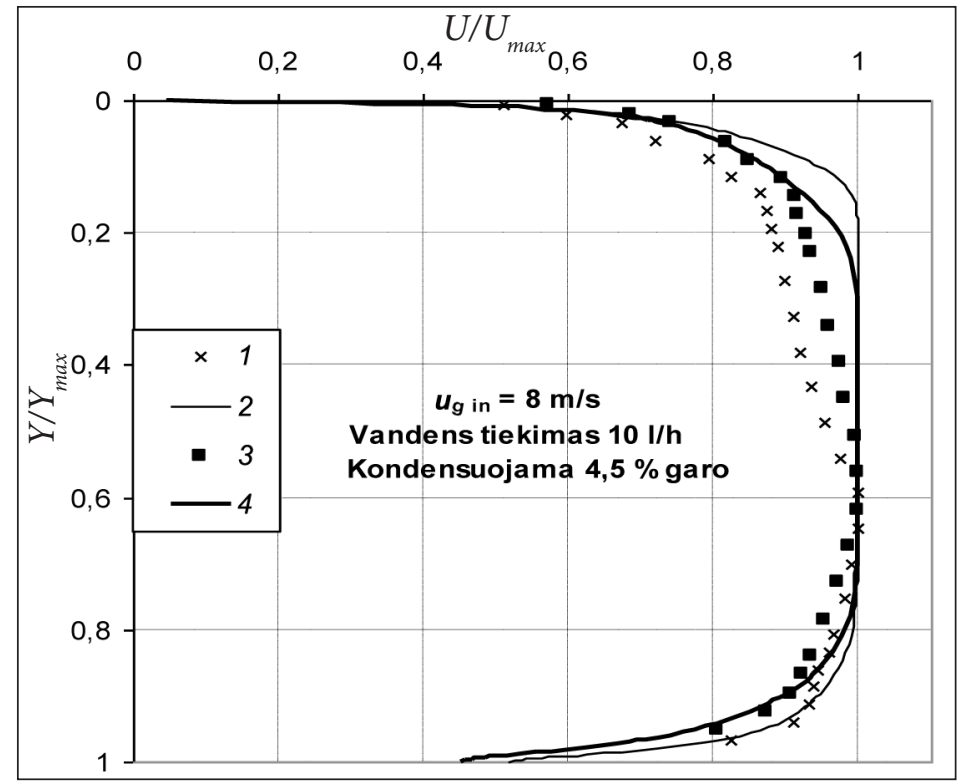

10 pav. Garo greičio profiliai kanale skirtingu atstumu nuo kanalo pradžios. 1 - matavimas $0,55 \mathrm{~m}, 2$ - FLUENT 0,55 m, 3 - matavimas $1 \mathrm{~m}$, 4 - FLUENT $1 \mathrm{~m}$ 


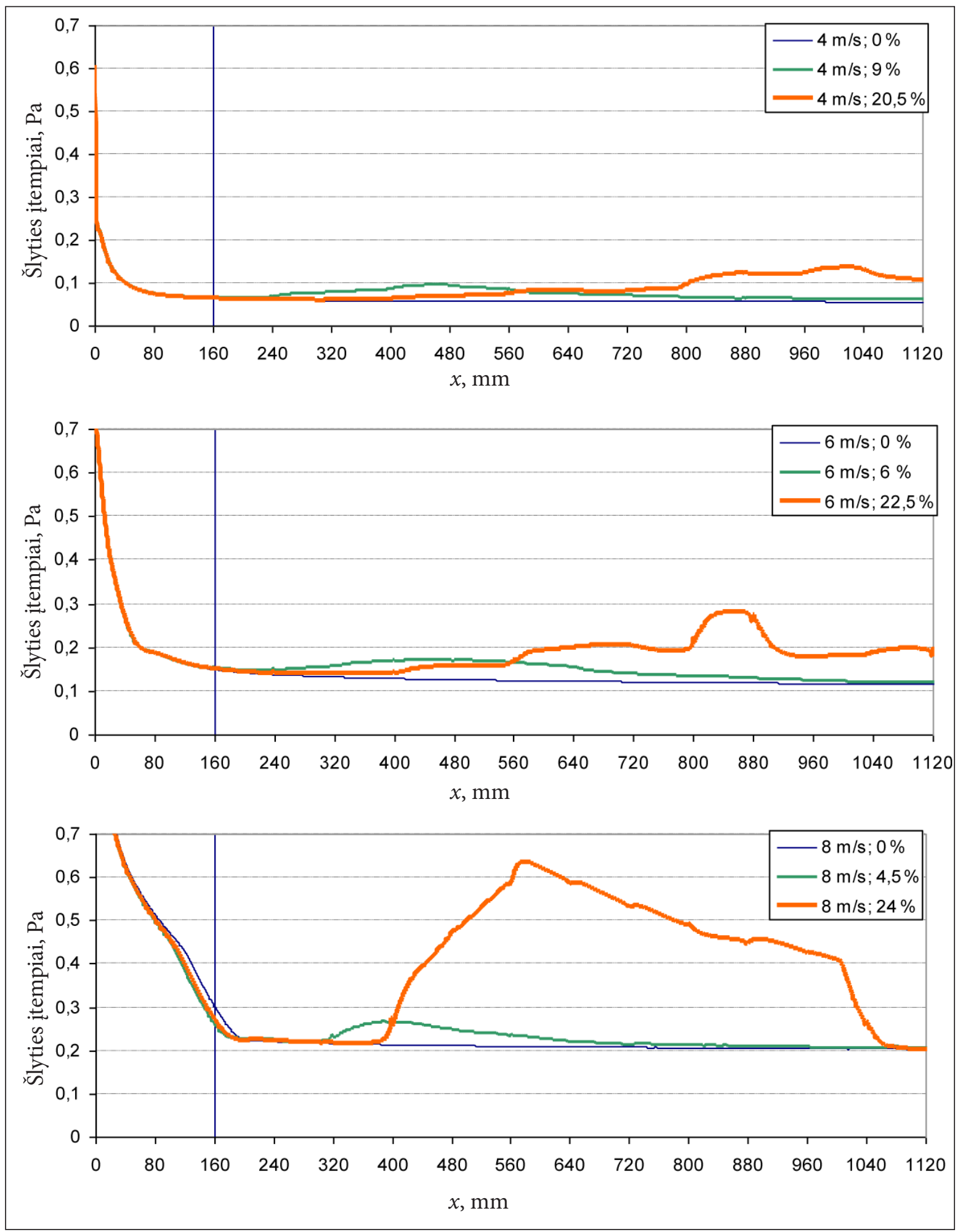

11 pav. FLUENT modeliu apskaičiuoti šlyties įtempiai išilgai kanalo esant skirtingoms garo įtekmei ir santykinei jos kondensacijai

greičiui ir $24 \%$ santykinei jo kondensacijai, tarpfazinès šlyties ịtempių pikas daugiau nei keturis kartus didesnis, palyginti su įtempiais nesant kondensacijos. Kita svarbi pastaba yra ta, kad didžiausio kondensacijos intensyvumo, taip pat ir tarpfazinès šlyties buvo tikimasi fazių kontakto pradžios vietoje, nes kanalo pradžioje yra didžiausias vidutinis garo ir vandens temperatūrų 


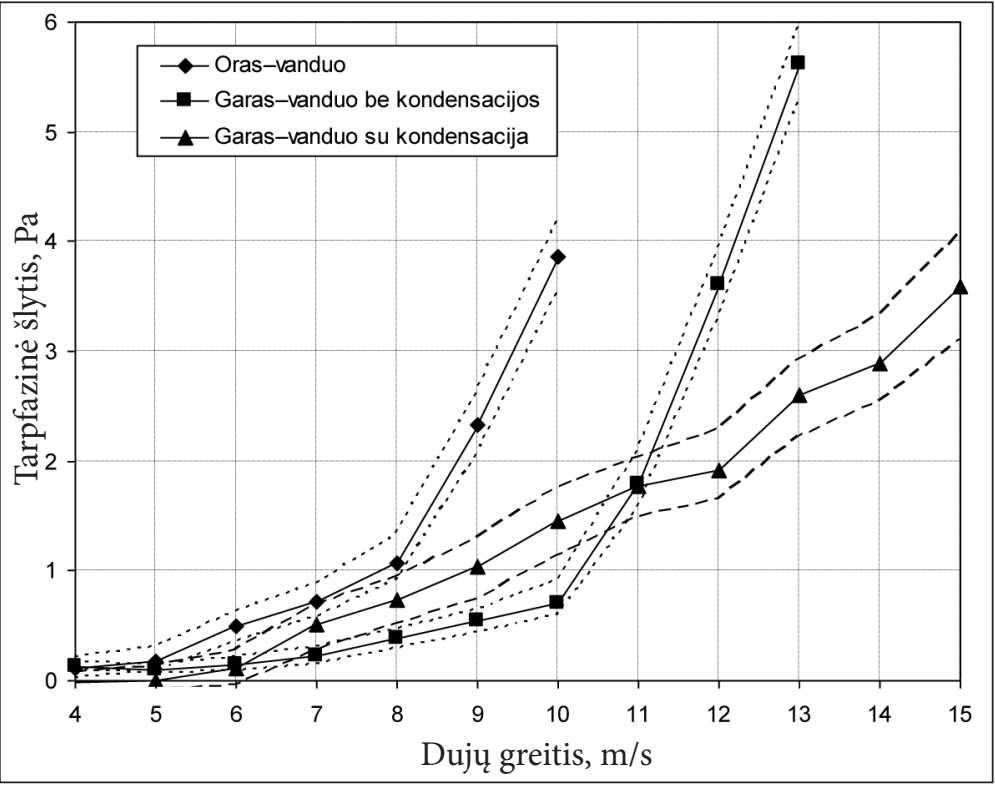

12 pav. Pagal slègio nuostolius apskaičiuoti tarpfazinio paviršiaus šlyties itempiai skirtumas. Toliau vykstant kondensacijai ir mažèjant temperatūros skirtumui kondensacija turètų slopti asimptotiškai. Tačiau, nagrinejjant 11 pav., tik $8 \mathrm{~m} / \mathrm{s} 4,5 \%$ režimo atvejis ị tai panašus. Visais kitais atvejais rezultatai aiškiai rodo, kad vidutinio temperatūros skirtumo tarp fazių įtaka yra nustelbiama kitų reiškinių, kurie aptariami kituose skyriuose, sąveikos.

Lygiagrečiai šiam FLUENT modeliavimui buvo vykdomi statinio slègio nuostolių tyrimai, esant skirtingiems dvifazio tekejimo deriniams. Statinio slègio nuostoliai susidaro dèl trinties ị sieneles ir vandens paviršių. Pašalinus trinties ị kietas sieneles dedamąją, apskaičiuotas vidutinès tarpfazinès trinties priklausomumas nuo garo tekejimo greičio ir kondensacijos. Palyginus 12 pav. ir 11 pav. rezultatus gautas geras vidutinių tarpfazinio paviršiaus šlyties ịtempių atitikimas patvirtina abiejų metodų patikimumą.

Kai virš vandens teka oras, jo greičiui esant apie $4 \mathrm{~m} / \mathrm{s}$, pradeda formuotis kapiliarinis bangavimas. Garo tankis dvigubai mažesnis nei oro, todèl bangavimas prasideda ties $6 \mathrm{~m} / \mathrm{s} .12$ pav. matoma, kad būtent toje zonoje, besikondensuojančio tekejimo tarpfazinès šlyties įtempiai viršija nesikondensuojančio. Tai įrodo, jog kondensacija šiame intervale (tirtuose režimuose 6-11 m/s) turi itakos tarpfazinio paviršiaus stabilumui ir jị mažina. Tai yra svarbi išvada, nurodanti, kad kondensacijos pliūpsnio eiga priklauso nuo nestabilumu, kylančiu tarpfaziniame paviršiuje.

\section{TURBULENCIJOS SUSIŽADINIMO VIZUALIZACIJA}

Paaiškejjus, kad, skirtingai nei tikètasi, kondensacijos intensyvumo kitimas išilgai termiškai nepusiausviro dvifazio tekejimo nèra asimptotinis, reikejjo ištirti to priežastis. Termografija, kuri sèkmingai taikoma vandens temperatūrai matuoti tiriant dvifazị tekejjimą $[12,13]$, buvo pasirinkta dèl didelès temperatūros lauko skiriamosios gebos ir aukšto matavimo dažnio. Skirtinguose skerspjūviuose ir esant skirtingiems garo greičio bei vandens debito deriniams termovizoriumi buvo registruojama temperatūros lauko kaita. Pagal sudarytą ir patikrintą vandens temperatūros matavimo metodiką dvimačiai temperatūros laukai buvo išmatuoti 90 matavimo taškų i $1 \mathrm{~mm}^{2}$ skyra. Temperatūros lauko matavimo dažnis buvo $50 \mathrm{~Hz}$. Analizuojant rezultatus atkreiptas démesys $\mathfrak{i}$ intensyvios turbulencijos suaktyvejjimo zoną, kurios pasireiškimo vieta priklauso nuo garo / vandens tekejjimo greičio ir temperatūros skirtumų. Kartu tekedami garas ir vanduo sąveikauja, todèl svarbiausias nagrinejjamo dvifazio besikondensuojančio tekejjimo parametras yra garo ir vandens greičiu skirtumas. Tarpfazinis paviršius veikiamas tarpfazinès trinties jèga, kuri priklauso nuo vietinio tarpfazinio greičio. Vykstant kondensacijai, vandens paviršius garo tèkmei tampa „pralaidžia sienele“. Todèl esant pastoviam vidutiniam fazių greičiu skirtumui vietinè 
jo reikšmè prie tarpfazinio paviršiaus gali kisti priklausomai nuo kondensacijos intensyvumo. Dèl tarpfazinès sąveikos pasroviui besikeičiančiu sąlygų vietinis tarpfazinis greitis iš pradžių mažèja, kadangi gerokai greičiau tekantis garas dèl trinties ir stabdomas, ir tekejjimo kryptimi stumia bei „šiaušia“ vandens paviršių. Tarpfazinio paviršiaus greitis išilgai kanalo nuolat didejja (igreitindamas ir po paviršiumi esantị vandenị), todèl vietinis tarpfazinis greitis toliau mažèja. Suintensyvejusi kondensacija padidina garo greiț prie pat vandens paviršiaus. Kondensacijai slopstant, kartu mažeja ir vietinis tarpfazinis greitis. Termonuotraukoje (13 pav.) gerai matoma šių procesų sukelto turbulencijos suaktyvejimo vandenyje zona.

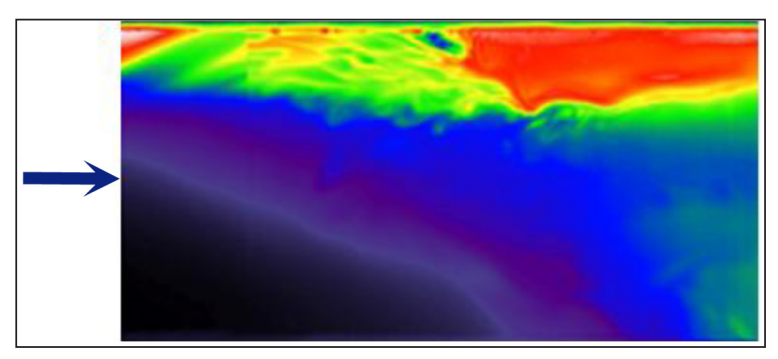

13 pav. Turbulencijos suaktyvëjimo zonos šiluminè nuotrauka (vidutinis vandens greitis $0,014 \mathrm{~m} / \mathrm{s}$, jtekančio vandens temperatūra $25^{\circ} \mathrm{C}$, garo j̇tekejjimo greitis $12 \mathrm{~m} / \mathrm{s}$ )

Nagrinejjant tyrimo rezultatus, vaizdinę informaciją ir atlikus vykstančių procesų tarpusavio ryšių analizę sudaryta galima turbulenciją sužadinančios tarpfazinės sąveikos seka:

- kylant vandens temperatūrai mažeja jo klampa ir tankis;

- veikiant Archimedo jègai karštas mažesnio tankio vanduo laikosi prie paviršiaus ir po juo susiformuoja plona, labai didelio temperatūros gradiento zona;

- šiame sluoksnyje vis kylant temperatūrai mažeja klampa ir Re dideja sparčiau, palyginti su giliau ir mažesniu greičiu tekančiu šaltesniu vandeniu. Dèl to po tarpfaziniu paviršiumi ploname sluoksnyje prasideda turbulencija;

- mažiau klampus paviršinis vanduo vis labiau igreitinamas virš jo tekančio garo. Turbulencija plinta gilyn ir atnaujindama paviršių (angl. surface renewal) šaltesniu vandeniu intensyvina kondensaciją;

- intensyvejjant kondensacijai vietinis virš vandens paviršiaus tekančio garo greitis dideja (kaip matyti 10 pav.) ir dar didesne jèga stumia tarpfazini paviršių;

- dèl vandens pagreitèjimo prie paviršiaus ir vienodo lygio per visą kanalo ilgi palaikymo (žr. 6 pav.) vandens tekejjimas apačioje lètëja, sustoja ar netgi keičia kryptị ị priešingą;

- tarpfazinis paviršius destabilizuojamas ir vandens sūkuriai pasroviui didèja, kol pasiekia apatinę kanalo sienelę.

Ši grižtamaisiais ryšiais susijusių procesų visuma paaiškina pradžioje silpnos kondensacijos eksponentinị išaugimą ir turbulencijos suintensyvèjimą. Šio reiškinio aktyviausios fazès - turbulencijos susižadinimo vieta kanale priklauso nuo garo ir vandens greičio derinio. Tačiau kondensacijos intensyvumo ir tarpfazinès sąveikos eksponentini augimą sustabdo vandens šilimas. Toliau tekant kanalu garo-vandens šiluminé nepusiausvira sparčiai mąžta ir, nuslopus kondensacijai, tarpfazinio paviršiaus šlytis vèl sumažèja (žr. 11 pav.). Kanalo gale vanduo jau yra pašilęs, o vandens maišymosi intensyvumas ir sūkurių dydis yra nepalyginamai mažesni nei turbulencijos suaktyvèjimo zonoje. Šių įžvalgų, paremtų tyrimo rezultatais, dèka gauta labai svarbi išvada, kad dvifazés tèkmés kondensacijos potencialas Ja* tiesiškai priklauso nuo vandens debito ir temperatūros, tačiau turbulencijos susižadinimui šiu vandens parametru įtaka nèra tiesine. Ju gana plataus intervalo kitimas nedaro reikšmingos įtakos turbulencijai, be to, abu turi ir priešingas, iš dalies vienas kita kompensuojančias, įtakas.

Tyrimo metu šiluminiai 2D laukai prie kanalo sienelès buvo fiksuojami didelès skyros ir dažnio termovizine kamera. Kadangi vandenyje vyrauja šilumos perdavimas konvekcija, tai kintant išmatuotam temperatūros laukui tuo pačiu fiksuojamas ir greičių laukas. Vizualiai stebint termovizoriumi nufilmuoto tekèjimo temperatūros lauko kitimą aiškiai matomi sūkuriai, pagal kuriuos galima nustatyti tekejjimo režimą. Norint objektyviai ịvertinti tekèjimo struktūrą, reikia matematinio šiluminių vaizdų apdorojimo ir tekejjimo struktūros ịvertinimo. Šiluminiams vaizdams analizuoti pritaikytas kombinuotas vietinio-bendrojo (CLG combined local-global) [14] metodas, fiksuojantis tiek tankius, tiek glotnius greičių laukus, ir leidžiantis aptikti vandens tèkmès turbulenciją. Tai aiškiai matoma nagrinejjant vandens turbulencijos vektorinius laukus, kai vyksta garo tèkmès sukelta vandens turbulencija po paviršiumi (14a pav.). Tai patvirtina 

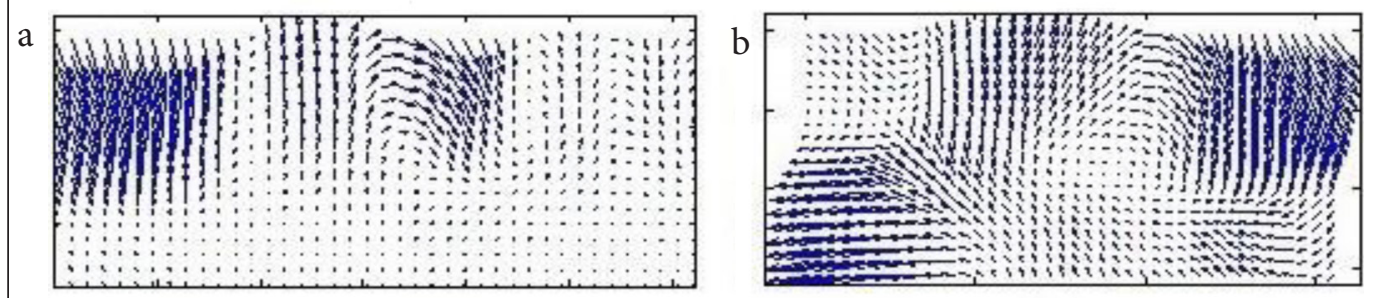

14 pav. Vandens tekejjimo greičio vektoriniai laukai: a - turbulencija prie vandens paviršiaus, b - visą vandens skerspjūvi apèmusi turbulencija

iškeltą hipotezę, kad kai ịkaitęs ir mažiau klampus paviršinis vanduo vis labiau igreitinamas virš jo tekančio garo, turbulencija plinta gilyn ir, atnaujindama paviršių šaltesniu vandeniu, intensyvina kondensaciją. Vandens aukštį apimantys dideli sūkuriai užfiksuoti, kai vyksta intensyvios, visą vandens skerspjūvị apimančios, turbulencijos sužadinimas (14b pav.).

\section{IŠVADOS}

Kondensacijos pliūpsniais varomos šiluminès hidraulinès sistemos koncepcija gali būti pritaikyta branduolinèse jègainėse, ji tinkama išpildyti pasyvaus aušinimo funkciją. Tokia sistema gali būti taikoma ir kituose pramonès įrenginiuose, kur generuojama šiluminè energija ir reikia priverstinès cirkuliacijos kontūre. Tokios sistemos privalumas sietinas su saugia eksploatacija, nes ji yra pasyvi, jai nereikia papildomos išorinès energijos. Tačiau tam, kad ši koncepcinè sistema veiktų, reikia išsamiai ištirti kondensacinio pliūpsnio reiškinį ir nustatyti jo susidarymo sąlygas. Tuo tikslu buvo atliekami eksperimentiniai ir skaitiniai tyrimai, leidžiantys daryti tokias išvadas:

1. Kondensacijos intensyvumo didejjimas gerokai stiprina tarpfazinę sąveiką, ir kondensacijos pliūpsnio eiga priklauso nuo nestabilumų, kylančių tarpfaziniame paviršiuje.

2. Dvifazès tèkmès kondensacijos potencialas $\mathrm{Ja}^{*}$ tiesiškai priklauso nuo vandens debito ir temperatūros, tačiau turbulencijai susižadinti šių vandens parametrų įtaka nèra tiesinè. Jų gana plataus intervalo kitimas nedaro reikšmingos įtakos turbulencijai, be to, abu veiksniai turi ir priešingas, iš dalies vienas kitą kompensuojančias, itakas.

3. Atlikti tyrimai parodo, kad vandens turbulencija gali būti apskaičiuojama ir vizualizuojama tekejjimo šiluminių vaizdų seką apdorojant kombinuotu vietinio-bendrojo Optinio srauto analizès metodu. Apibendrinus vektorinius vandens greičių laukus, šie duomenys gali būti panaudoti dvifazio besikondensuojančio tekejjimo turbulencijos intensyvumui prognozuoti.

Gauta 20160630 Priimta 20160909

\section{Literatūra}

1. Block J. A. Condensation-driven fluid motions. International Journal of Multiphase Flow. 1980. Vol. 6. No. 1-2. P. 113-129.

2. Štrubel J. L., Tiselj I. Condensation of the steam in the horizontal steam line during cold water flooding. International Conference Nuclear Energy for New Europe 2006, September 2006, Portorož, Slovenia. P. 18-21.

3. Kryukov A. P., Yastrebov A. K. Vapor condensation at sudden contact with cold liquid in non-equilibrium conditions. Proceedings of the 14th International Heat Transfer Conference IHTC14-22625. 2010.

4. Hughes E. D., Duffey R. B. Direct contact condensation and momentum-transfer in turbulent separated flows. International Journal of Multiphase Flow. 1991. Vol. 17(5). P. 599-619.

5. Khan A., Haq U. N., Chughtai I. R., Shah A., Sanaullah K. Experimental investigation of the interface between steam and water two phase flows. International Journal of Heat and Mass Transfer. 2014. Vol. 73. P. 521-532

6. Louahlia-Gualous H., Mecheri B. Unsteady steam condensation flow patterns inside a miniature tube. Applied Thermal Engineering. 2007. P. 1225-1235. 
7. Pabarcius R., Seporaitis M., Almenas K. Investigation of condensation implosion event. Heat Transfer Research. 2004. Vol. 35. Iss. 78. P. 531-548.

8. RELAP5/MOD3.3 code manual.

9. Almenas K., Pabarčius R., Šeporaitis M. Design and tests of a device for the generation of controlled condensation implosion events. Heat Transfer Engineering. 2006. Vol. 27. Iss. 3. P. 32-41.

10. Gupta D., Park Y. G., Jacobi A. M. An experimental study of condensate retention on the air side of flat tube heat exchangers. Proceedings of the 14th International Heat Transfer Conference, 8-13 August 2010, Vol. 2, Washington, DC, USA. Inc. Paper IHTC14-22986. P. 227-234.

11. Bestion D. The difficult challenge of a two-phase CFD modelling for all flow regimes. Nuclear Engineering and Design. 2014, Vol. 279. P. 116-125.

12. Hetsroni G., et al. Infrared temperature measurements in micro-channel and micro-fluid systems. International Journal of Thermal Sciences. 2011. Vol. 20. P. 853-868.

13. Kim T. H., et al. Measurements of two phase flow and heat transfer parameters using infrared thermometry. International Journal of Multiphase Flow. 2012. Vol. 40. P. 56-57.

14. Jara W. J., Cerda M., Delpiano J., Hartel S. An implementation of combined local-global optical flow. Image Processing on Line. 2015. Vol. 5. P. 139-158.
Marijus Šeporaitis, Mindaugas Valinčius, Stasys Gasiūnas, Darius Laurinavičius, Raimondas Pabarčius, Algirdas Kaliatka, Kazys Almenas

\section{INVESTIGATION OF INTERFACIAL} INTERACTION AND CONDENSATION

\section{Summary}

An overview of the numerical and experimental investigations of condensation of two-phase flow performed in 2005-2015 is presented in the article. The concept of thermal hydraulic scheme, in which coolant circulates driven by condensation, as well as the experimental facility, employed investigation methods and obtained results are presented. The influence of condensation intensity on interfacial shear was investigated combining experimental data and numerical results. The examination of the turbulence structure in the experimental rectangular channel using optical methods of thermography and mathematical image analysis revealed the phenomenon of the turbulence self-excitation in condensing twophase flow.

Keywords: condensation, turbulence, two-phase flow, interfacial interaction 